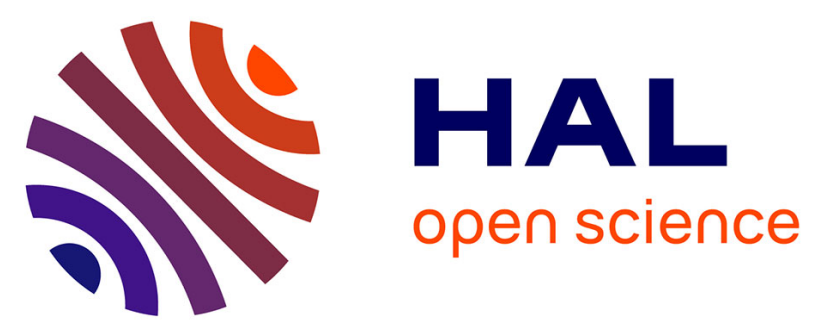

\title{
Study of the involvement of research ethics committees in the constitution and use of biobanks in France.
}

Grégoire Moutel, Sandrine de Montgolfier, Nathalie Duchange, Lama I. Sharara, Catherine Beaumont, Christian Hervé

\section{- To cite this version:}

Grégoire Moutel, Sandrine de Montgolfier, Nathalie Duchange, Lama I. Sharara, Catherine Beaumont, et al.. Study of the involvement of research ethics committees in the constitution and use of biobanks in France.. Pharmacogenetics -London-, 2004, 14 (3), pp.195-8. inserm-00143041

\section{HAL Id: inserm-00143041 https://www.hal.inserm.fr/inserm-00143041}

Submitted on 25 Apr 2007

HAL is a multi-disciplinary open access archive for the deposit and dissemination of scientific research documents, whether they are published or not. The documents may come from teaching and research institutions in France or abroad, or from public or private research centers.
L'archive ouverte pluridisciplinaire HAL, est destinée au dépôt et à la diffusion de documents scientifiques de niveau recherche, publiés ou non, émanant des établissements d'enseignement et de recherche français ou étrangers, des laboratoires publics ou privés. 


\section{Study of the involvement of research ethics committees in the constitution and use of biobanks in France}

Grégoire Moutel, Sandrine de Montgolfier, Nathalie Duchange, Lama Sharara, Catherine Beaumont and Christian Hervé

Laboratoire d'éthique médicale, de droit de la santé et de santé publique \& Institut International de Recherche en Ethique Biomédicale (IIREB)

Faculté de Médecine Paris-Necker; Université Paris V René Descartes 156 rue de Vaugirard, 75015 Paris, France www.inserm.fr/ethique

Running title: Research Ethics Committees and Biobanks

Key words: Research Ethics Committee, Genetic Databases, Biomedical Research, Human Genetics, Collections, Informed Consent, Human Biological Resources.

Correspondence to: Dr Grégoire Moutel

Laboratoire d'éthique médicale, de droit de la santé et de santé publique

Faculté de Médecine Paris-Necker; Université Paris 5 René Descartes

156 rue de Vaugirard, 75730 Paris, France

Tel: +33(0)140615652-fax : +33(0)140615588

moutel.gregoire@wanadoo.fr 


\begin{abstract}
Concerns are emerging about the protection of persons taking part in genetic research involving biobanks. We used several items of a questionnaire sent to the 48 French research ethics committees (RECs) to investigate the means by which they evaluate the constitution and use of biobanks and the elements on which conclusions were based.
\end{abstract}

Most RECs felt they should evaluate the constitution of biobanks in protocols, but not all did so in practice. Harmonization of the competence of RECs for evaluating biobanks is required, particularly concerning information, consent, the duration of sample conservation and the communication of research results. Our results and others demonstrate the need to develop rules and guidelines based on common ethical approaches, particularly in the European environment. 


\section{INTRODUCTION}

The collection of human biological material and phenotypic data is essential for genetic research. The French Code of Public Health $(\mathrm{CPH})$ defines a collection, in the context of genetic research, as a cluster of "biological samples for use in genetic research, obtained from a group of identified patients selected according to the clinical or biological characteristics of one of more members of a group, as well as any and all derivatives of these samples" (art L.1131-4). It may consist of solid tissues, blood, saliva, or any other tissue or fluid containing nucleated cells. The biological material is associated with files (often computer files) that may contain identified, identifiable, directly anonymous data or data rendered anonymous (anonymized). We will use the term "biobank" to cover all activities relating to the storage of human biological materials.

In theory, RECs must approve all biomedical research studies, including those involving the collection of human materials, which may cause harm to the individual in his psychological and social dimensions. This view was laid down in the 1975 Declaration of Helsinki. In France, the "Huriet Law" of December 20, 1988 [1], now part of the $\mathrm{CPH}$, sets out the legal requirements concerning the protection of individuals involved in biomedical research. It has led to the constitution of RECs, also known as CCPPRBs (for Consultative Committees Protecting Persons in Biomedical Research) in France. Today, there are 48 RECs in France. The recommendations formulated by the committees are transmitted to the Ministry of Health, which can independently review an opinion if judged necessary. The role of the committees, as defined by law (article L$1123 \mathrm{CPH}$.), is to evaluate the validity of research in terms of the protection of participants in general, and concerning particularly informed consent of participants, 
methods of obtaining consent, indemnification of the participants, general relevance of the project and whether the means available and the qualifications of the investigators involved are sufficient.

Ethical and legal issues raised by the constitution of biological collections include organizational and medical aspects of storage duration and sample reuse. Some studies have explored practices concerning the constitution and use of collections [2-4]. In pharmacogenetic studies, clarification of the procedures concerning confidentiality, information sharing and guarantees concerning DNA storage and usage are required [5]. In 1994 [6], it was suggested that "...the constitution of the collection...requires the opinion of the REC" and, in 1998 [7], that "...an agreement will take into account measures involved in the collection, storage and abusive use (such as use in the context of employment, insurance ...) of samples and any information concerning them".

In this study, we investigated the views of French RECs concerning their current and ideal involvement in the constitution and use of biobanks and concerning the ethical rules necessary to protect people involved in this kind of activity.

\section{METHODS}

We used a questionnaire with open and closed questions. This questionnaire was validated by a multidisciplinary team working in the Laboratory of Ethics and Public Health at the Necker Faculty of Medicine, Paris, France. It was approved by the national REC conference chairman and six former REC members. The questionnaire and a letter explaining the aims of the study, the definition of biobank to be used, and a list of 
French recommendations and laws was sent to the president of each of the 48 French RECs. The questionnaire was completed by the president of each committee after discussion and validation by REC members generating a consensus. Replies to closed questions were analyzed using Excel software. The research team analyzed directly the content of responses to open questions. Four items from the questionnaire and the results are presented in table 1.

\section{RESULTS}

Twenty-eight of the 48 RECs (around 60\%) completed the questionnaire, suggesting that many of the RECs, distributed throughout France, are concerned about the problems addressed and wish to be involved in the evaluation of practices. No difference in terms of size or structure was observed between the RECs that responded and those that did not. Lack of time may have been responsible for the lack of response in some cases.

Twenty-five of the RECs thought approval should be sought from an REC when creating a biological collection. Only three RECs disagreed, for different reasons. One expressed doubts about their ability to evaluate the constitution and/or use of biobanks and the means of following up and assessing the fate of the samples. Another argued that this task should be the responsibility of the CNIL (the French Data Protection Agency [DPA]), which protects individual rights concerning the computerization of medical data used in research. The third highlighted a problem encountered when biological material is collected in the absence of a specific research project; should 
biobanks constructed in this way be considered biomedical "research" requiring the approval of a REC?

The RECs focused principally on the consent form, information to the patient, confidentiality and the communication of results to the patient (item 3, table 1). Most RECs took into account the constitution or use of a biological collection, although six said they did not.

The responses to item 5 demonstrate that RECs were primarily concerned about (i) protecting the participant (ii) informing the participant at the time of sampling, (iii) obtaining consent, and (iii) evaluating the ways in which confidentiality is handled. They were less concerned about management aspects, such as the handling of the collected data, when making decisions about biobanks.

\section{DISCUSSION}

The RECs generally agreed that their opinion should be sought for the constitution of a biobank and that they have a particular responsibility in the use of samples. The RECs not concerned about the ethical evaluation of biobanks may feel this way because the $\mathrm{CPH}$ has not clearly identified banking activities as being part of the tasks of an REC [4].

Historically, the role of the RECs was to evaluate clinical trials that might affect the physical integrity of the person. Changes in human research have extended their competence to protocols potentially affecting not only physical integrity but also the 
identity (social and familial) of the person, bringing psychological and spiritual aspects to the forefront. If a person is considered in all these dimensions, not just as a physical being, then it is appropriate for ethics committees to assess biobanks. The concept of protecting persons, as stipulated by law, and concerning both users of the health system and research participants, may be central when developing biomedical research projects involving new biobank technology, and should not be restricted to classical therapeutic trials. This concept of protecting individuals from whom DNA samples are collected differs from that in most other clinical protocols or experiments on humans, but this does not lessen its importance.

Who should be responsible for ensuring the protection of human subjects in the management of a biobank? In France, the French Data Protection Agency [DPA] or CNIL, has been proposed. In this case, evaluation would be limited to the protection of individual rights associated with the computerization of medical data used in research. According to the former NBAC (National Bioethics Advisory Commission of the USA), it is essential that IRBs (Institutional Review Boards) evaluate research involving human biological resources [8]. The integration of biobank evaluation into the work of RECs has been proposed as part of a project to revise French law concerning biomedical research, with a view to applying a European directive [9-10].

The RECs appear to be appropriate bodies for evaluating research projects involving biobanks. They are concerned about the necessity to inform participants, to obtain consent for sample use, confidentiality, and decisions concerning the transmission of research findings to the participants. These points are coherent elements in the 
recognized role and daily practice of RECs. However, questions concerning the fate of the bank and conditions of access and exchange appear to be taken into account to a lesser extent.

The RECs also have a role to play in determining whether overall and/or individual results should be transmitted to participants. They may be involved in the decision to use directly anonymous data (no link between the data and the participant) or to render identifiable data anonymous (thereby destroying the link between the sample and the individual). The use of anonymous data precludes the communication of individual results and this element must be considered when consent is sought.

Standardized consent forms for use in genetics have been proposed [11-12]. Clauses have been drafted for numerous issues: sample storage, benefits, risks, confidentiality, communication of results to the patients, genetic counseling, possibilities of transfer or commercialization, and time for reflection before giving consent. International harmonization of ethical controls on genetic research projects would be desirable, rendering consistent the rules applied to the content of information, the consent form, and the functioning of biobanks. This is becoming increasingly important with the growing number of international projects and differences in the constitution, use, reuse and transfer of biological samples. Indeed, these activities are not necessarily routinely evaluated by RECs as they are not covered by laws concerning biomedical research. 


\section{ACKNOWLEDGMENTS}

We would like to thank all of the members of the French RECs who took the time to answer the questionnaire and Alex Edelman \& Associates for language editing. 


\section{REFERENCES}

1. France. Law $\mathrm{N}^{\circ} 88-1138$ of December $20^{\text {th }}$, 1988 on the protection of persons accepting biomedical research (Huriet Law) revised July 25th, 1994. Journal Officiel 1988; 26 juillet 1994:10747-49.

2. Merz J, Leonard D, Miller E. IRB review and consent in human tissue research. Science 1999; 283:1647-1648.

3. McEwen JE, Reilly PR. A survey of DNA diagnostic laboratories regarding DNA banking. Am J Hum Genet 1995; 56(6):1477-86.

4. Weir RF, Horton JR. DNA banking and informed consent - part 2. Irb 1995; 17(5$6): 1-8$.

5. de Montgolfier S., Moutel G., Duchange N., et al. Ethical reflexions on pharmacogenetics and DNA banking in a cohort of HIV-infected patients. Pharmacogenetics $2002 ; 12(9)$ : 667-675.

6. Louisot P. [Rapport sur la protection intellectuelle des résultats de recherche sur le génome humain et les banques de cellules et de données sur l'ADN. Paris, Ministère de l'Enseignement supérieur et de la recherche, Dictionnaire permanent de bioéthique et biotechnologies]. Editions Législatives. 1994: 9692-9695.

7. CCNE. Avis N60 - [Réexamen des lois de bioéthiques : Problèmes éthiques posés par la constitution et l'utilisation de collections d'échantillons biologiques en génétique humaine. Section technique du CCNE 13/05/94]. France: Comité Consultatif National d'Ethique, 1998.

8. NBAC Report on research involving human biological materials: ethical issues and policy guidance. USA, National Bioethic Advisory Commission, 1999. 
9. Directive 2001/20/ec of the European parliament and of the Council, dated 4th of April 2001, on the nearness of the laws, regulations and administrative procedures of the Member States, relating to the implementation of good clinical practice in the conduct of clinical trials on medicinal products for human use. Official Journal of the European Communities 2001, L 121/34.

10. France. Projet de loi relatif à la bioéthique. 2003. Sénat $n^{\circ} 63, \mathrm{AN} \mathrm{n}^{\circ} 593$. www.assemblee-nat.fr.

11. Deschenes M, Cardinal G, Knoppers BM, Glass KC. Human genetic research, DNA banking and consent: a question of 'form'? Clin Genet 2001; 59(4):221-39.

12. Beskow LM, Burke W, Merz JF, et al. Informed consent for population-based research involving genetics. JAMA 2001; 286(18):2315-21 